МІЖНАРОДНЕ ПРАВО

УДК 341.645.018:342 (477)

DOI https://doi.org/10.32844/2618-1258.2019.6.59

ТИХОМИРОВА Г.Є., БАЛДЖИ К.В.

\title{
СИСТЕМНІ ПРОБЛЕМИ УКРАЇНСЬКОГО ЗАКОНОДАВСТВА В КОНТЕКСТІ «ПІЛОТНИХ РІШЕНЬ» ССПЛ
}

Статтю присвячено системним проблемам українського законодавства у контексті прийняття «пілотних рішень» Європейського суду з прав людини. Важливим джерелом, що проголошує права та свободи особи, є Конвенція про захист прав людини і основоположних свобод, яка кожному гарантує право на ефективний засіб юридичного захисту. Так, виконання рішень національних судових органів $\epsilon$ суттєвим складником захисту порушеного права особи. Європейський суд 3 прав людини як авторитетний правозахисний орган звертає увагу на проблему невиконання остаточних судових рішень, зокрема за рахунок прийняття ним «пілотного рішення».

Проаналізовано властивості «пілотних рішень» ССПЛ і рішень щодо України, а також причини невиконання рішень національних судових органів. Досліджено, що саме недосконалість законодавчої бази є підгрунтям для виникнення відповідних причин.

Розглянуто пропозиції науковців стосовно поліпшення ситуації із невиконанням судових рішень. Окреслено переваги та недоліки таких варіантів, а також надано посилання на міжнародний досвід у вирішенні подібної проблеми. Так, опрацьовано рішення ЄСПЛ "Olaru and others v. the Republic of Moldova" та виявлено потенційно прийнятний для української влади механізм дії у відповідь на «пілотні рішення» Європейського суду з прав людини. В той же час акцентовано увагу на неможливості повністю дублювати іноземний досвід у вирішенні подібних проблем, оскільки не слід забувати про особливості національної правової системи.

Наголошено, що Європейський суд з прав людини не лише вказує на недостатність заходів і недоліки у вирішенні проблеми українською владою, а й максимально сприяє ії вирішенню. Так, згадано про рішення Комітету Ради Європи та впровадження проєкту Ради Європи, що має назву «Підтримка виконання Україною рішень Європейського суду з прав людини».

Зроблено висновок про необхідність прийняття комплексної стратегії, яка враховувала б різні напрями, 3 метою вирішення проблеми невиконання остаточних судових рішень як системної проблеми. Серед напрямів названо законодавчий, структурний, фінансовий, експертний.

Ключові слова: Свропейський суд з прав людини, пілотне рішення, євроінтеграчія, невиконання судових рішень, системна проблема, стратегія.

The article deals with the systemic problems of the Ukrainian legislation in the context of making "pilot decisions" of the European Court of Human Rights. An important source proclaiming the rights and freedoms of the individual is the Convention for the Protection of Human Rights and Fundamental Freedoms, which guarantees everyone

(C) ТИХОМИРОВА Г.С. - кандидат юридичних наук, доцент кафедри права та публічного адміністрування (Маріупольський державний університет)

( Б) БАЛДЖИ К.В. - студентка кафедри права та публічного адміністрування (Маріупольський державний університет) 
the right to an effective remedy. Thus, the enforcement of decisions of national judicial authorities is an essential component of the protection of the person's rights violated. Accordingly, the European Court of Human Rights, as a respected human rights body, draws attention to the problem of non-enforcement of final judgments, in particular by making it a "pilot decision".

The properties of the "pilot decisions" of the ECHR in General and decisions regarding Ukraine in particular, as well as the root causes of non-compliance with the decisions of national judicial authorities, are analyzed. It is investigated that the imperfection of the legal framework is the basis for the occurrence of the corresponding reasons.

The article considers the proposals of scientists to improve the situation with non-execution of court decisions. The advantages and disadvantages of such options are identified, as well as references to international experience in solving such a problem. Thus, the decision of the ECHR "Olaru and others V. the Republic of Moldova" was processed and the mechanism of action that is potentially acceptable for the Ukrainian authorities in response to the "pilot decisions" of the European court of human rights was identified. At the same time, attention is focused on the impossibility of completely duplicating foreign experience in solving such problems, since we should not forget about the peculiarities of the national legal system.

It is noted that the European court of human rights not only points out the insufficiency of measures and shortcomings in solving the problem by the Ukrainian authorities, but also contributes to its solution as much as possible. Thus, the decision of the Committee of the Council of Europe and the implementation of the project of the Council of Europe is referred to as "Support for Ukraine's implementation of the decisions of the European court of human rights".

It is concluded that it is necessary to adopt a comprehensive strategy that would take into account different directions in order to solve the problem of non-execution of final court decisions as a systemic problem. Among the areas mentioned are legislative, structural, financial, and expert.

Key words: European Court of Human Rights, pilot decision, European integration, non-enforcement of court decisions, systemic problem, strategy.

Вступ. Натепер актуальним залишається питання євроінтеграції нашої країни. Цей процес $\epsilon$ не можливим без наближення національного законодавства до правових стандартів розвиненої європейської спільноти. У такому напрямі наша країна прямує не перший день, і вагомим кроком стала ратифікація у 1997 році Конвенції про захист прав людини і основоположних свобод (далі - Конвенція) та подальше прийняття Протоколів до неї. Конвенцію називають «європейським біллем про права», вона широким блоком проголошує права і свободи особи, містить дієвий механізм їх захисту, в тому числі за рахунок функціонування Європейського суду з прав людини (далі - ЄСПЛ).

Законом про ратифікацію Конвенції встановлено повне визнання Україною обов'язкової юрисдикції ЄСПЛ стосовно всіх питань тлумачення та застосування Конвенції. Конвенцією визначено право кожного на ефективний засіб юридичного захисту. На національному рівні завершальним етапом у здійсненні функції захисту порушених прав і свобод громадян $\epsilon$ виконання рішень національних судових органів. Проте далеко не всі остаточні судові рішення виконуються, що є системною проблемою. На це вказують і рішення ЄСПЛ щодо України, які отримали назву «пілотних». Отже, підкреслюючи наше прагнення бути правовою європейською державою, слід вказати на актуальність проблеми не виконання остаточних судових рішень, яке повинно бути завершальним етапом ефективного механізму захисту порушених прав та свобод людини і громадянина.

Постановка завдання. Метою статті є аналіз існуючих та пошук нових пропозицій щодо вдосконалення механізму виконання національних судових рішень крізь призму «пілотних рішень» ЄСПЛ відносно України.

Результати дослідження. Для практики ЄСПЛ вагоме значення має процедура прийняття «пілотного рішення». Характерно, що визначення останнього не міститься у Конвенції про захист прав людини і основоположних свобод. Але загальні ознаки, притаманні для «пілотного рішення», були сформовані вже в першому пілотному рішенні ЄСПЛ Broniowski v. Poland (2004 p). Надалі процедура прийняття відповідного рішення ЄСПЛ була закріплена спеціальною 
нормою Регламенту суду [1, с. 735]. Так, можна виокремити найсуттєвішу особливість такого рішення: вказівка на системний характер проблеми у національному законодавстві, яка $є$ причиною порушення положень Конвенції. До того ж таким рішенням здійснюється аналіз ситуації, яка призвела до великої кількості однотипних порушень із боку держави-відповідача [2, с. 244]. Отже, процедура «пілотного рішення» ЄСПЛ з одного боку раціональна для суду за рахунок його розвантаження, з іншого стимулююча для держави-відповідача, оскільки дає змогу вирішити наявну проблему на національному рівні.

Практичний інтерес у межах дослідження мають два «пілотних рішення» ССПЛ стосовно України. Першим рішенням «Іванов проти України» (2009р.) ЄСПЛ вказав, що держава не може виправдовувати невиконання судових рішень, винесених стосовно органів державної влади, нестачею коштів. Судом було вказано на проблеми української правової системи, зокрема на відсутність необхідних бюджетних коштів, недоліки виконавчої системи та прогалини у законодавстві. Суд також наголошує на системному характері цієї проблеми і пропонує здійснити комплексні заходи законодавчого характеру. Реакцією на пілотне рішення стало, зокрема, прийняття Закону України «Про гарантії держави щодо виконання судових рішень». Але проблеми це не вирішило і через виключення положень про обмеження мораторію на відчуження державного майна та обмеження соціальних виплат. Тим не менш, було підкреслено певні прагнення української влади до вирішення проблеми, проте з урахуванням перелічених вище чинників повністю цього не вдалося досягти. Вже 2017 року мало місце друге рішення ЄСПЛ «Бурмич та інші проти України», яким було наголошено в досить рішучих формулюваннях про невирішену проблему невиконання Україною рішень національних судів [3, с. 22].

Отже, через процедуру прийняття «пілотних рішень» ЄСПЛ вказав на системний характер окресленої вище проблеми. Оскільки йдеться про системність, то і вирішення цієї проблеми потребує комплексного підходу. Це означає, що мають враховуватися причини цього вкрай негативного явища, бо інакше не можливо створити механізм їх подолання, а також необхідне запровадження стратегії оптимальних кроків держави на законодавчому рівні.

Щодо причин проблеми не виконання остаточних судових рішень, то дослідники відносять до них такі: недосконала законодавча база стосовно системи виконання судових рішень, відсутність ефективних механізмів примусового виконання, відсутність належного моніторингу, недостатня розробленість засобів правового захисту та інші. Деякі науковці ще наголошують на такій причині як недостатня політична воля. На іiї недостатність вказує той факт, що на законодавчому рівні закріплено обов'язок держави виконувати судові рішення, ухвалені проти неї, але держава значно більше зацікавлена у виконанні судових рішень на їі користь [4, с. 19].

Другим важливим аспектом $€$ запровадження стратегії, тобто певного курсу держави для вирішення системної проблеми. Розуміння такої потреби як з боку правозахисних інституцій в обличчі ЄСПЛ, так і з боку українських органів влади не є новим. Більше того, Комітет Міністрів Ради Європи запропонував трикрокову стратегію подолання проблеми, на яку вказано «пілотним рішенням» ЄСПЛ щодо України. Здебільшого вона стосується погашення заборгованості та відповідного фінансування. Не дивлячись на це, проблема залишалася не вирішеною [4, с. 20].

Науковці пропонують різні варіанти поліпшення ситуації з не виконанням судових рішень. Так, одні рекомендують користуватися правом забезпечення позову, хоча тут слід враховувати необхідність серйозної обгрунтованості такого заходу. Інші пропонують створити фонд, який би гарантував здійснення виплат за судовими рішеннями. Треті наголошують на необхідності створити окремі, нові органи контролю за виконанням судових рішень.

На думку авторів, алгоритм дій для поліпшення ситуації із невиконанням судових рішень не може складатися 3 двох, трьох або чотирьох кроків. Вони переконані, що це повинна бути стратегія, яка, окрім всього, повинна враховувати і міжнародний досвід. Наприклад, за «пілотним рішенням» ССПЛ "Olaru and others v. the Republic of Moldova” виокремлюється системна проблема, пов'язана з не виконанням Молдовою судових рішень про надання соціального житла. У відповідь на «пілотне рішення» Молдовою прийняті такі кроки: послідовне реформування законодавства та введення нових внутрішніх засобів правового захисту. ЄСПЛ, аналізуючи таку реакцію молдавської влади на «пілотне рішення», дійшов висновку, що це цілком відповідає суті наданих рекомендацій. Значно спрощеною стала процедура розгляду подібних справ і виконання прийнятих рішень відповідно до цього розгляду [5, с. 5].

Зрозумілим є той факт, що кожна країна має свої особливості правової системи і системи виконання судових рішень. Але певний досвід країн, які вже мають позитивні тенденції з окресленого питання, має свою цінність і повинен бути використаний. Важливо, що Європейським 
судом з прав людини відносно України не лише було прийнято друге пілотне рішення, яке знову вказало на проблему та недостатність заходів щодо ії вирішення. Принциповим є прагнення європейських інституцій допомогти українській владі змінити ситуацію докорінно. Йдеться, зокрема, про проєкти Ради Європи та звіти Комітету Ради Європи. Так, у червні 2019 року мали місце певні рішення комітету, якими акцентовано увагу на недоліках у розумінні проблеми. Вказано, що в Україні відсутнє загальне бачення причин проблеми невиконання судових рішень на національному рівні та не прийнято всеохоплюючої стратегії для вирішення цієї проблеми [6].

Слід зазначити, що впроваджено також проєкт Ради Європи «Підтримка виконання Україною рішень Європейського суду з прав людини», яким організовані експертні дискусії та надані певні рекомендації. В межах проведених дискусійних заходів було виявлено певну особливість: українська влада надає більший пріоритет у виконанні судових рішень за справами, які пройшли процедуру розгляду ЄСПЛ, аніж тих, що такої процедури не проходили. 3 одного боку таке визнання авторитету ЄСПЛ лише вітається і є позитивним. 3 іншого це створює низку негативних явищ, серед яких зменшення значущості обов'язкової сили рішень національних судових органів та недовіра до судової влади [4, с. 22]. Варто розуміти, що метою всього проєкту підтримки виконання Україною рішень ЄСПЛ є формування в української влади розуміння, що ЄСПЛ є субсидіарним, авторитетним судовим органом, але не черговою судовою інстанцією, яку має пройти заявник, щоб домогтися виконання рішення.

Висновки. Проаналізувавши викладене вище було встановлено, що «системний характер» проблеми, на який вказано пілотними рішеннями ЄСПЛ щодо України, потребує «системного» підходу до її вирішення.

Авторипропонують впровадження багатокроковоїстратегії, яка бвраховувалатакі напрями:

- законодавчий (реформа виконавчої системи на предмет надання

- реальних механізмів для виконання судових рішень; перегляд системи мораторіїв; удосконалення засобів правового захисту);

- структурний (створення окремої системи моніторингу за виконанням

- судових рішень; створення спеціальних фондів гарантування);

- фінансовий (відповідне планування бюджетних коштів і можливість

- отримання надходжень від міжнародних організацій);

- експертний (використання міжнародного позитивного досвіду з організацій).

- вирішення подібних проблем, врахування рекомендацій авторитетних правозахисних

Факт того, що ЄСПЛ як авторитетний правозахисний орган акцентує увагу на системній проблемі в нашій країні в напрямі захисту прав людини беззаперечно зумовлює необхідність подальших наукових досліджень і розробок з метою врегулювання цього проблемного питання. До того ж момент із впровадженням нового засобу правового захисту залишається відкритим.

\section{Список використаних джерел:}

1. Kurban D. Forsaking Individual Justice: The implications of the European Court of Human Rights Pilot Judgment Procedure for Victims of Gross and Systematic Violations. Human Law Review. 2016. Vol. 16. P. 731-769.

2. Гончаренко О.А. Правова природа «пілотних рішень» Європейського суду з прав людини. Форум права. Харків, 2012. № 4. С. 243-249.

3. Белікова С.О., Белікова А.О. «Пілотні рішення» Європейського суду з прав людини та проблема невиконання рішень національних судів. Практика Європейського суду з прав людини в діяльності органів прокуратури і суду: виклики та перспективи : матеріали міжнар. наук.-практ. конф., м. Київ, 13 червня 2018 р. Київ, 2018. С. 21-24.

4. Звіт за результатами експертних дискусій щодо виконання національних судових рішень у контексті рішень Європейського суду з прав людини «Юрій Миколайович Іванов проти України» та «Бурмич та інші проти України». URL: https://rm.coe.int/expert-report-followinga-series-of-expert-discussions-ukr/16808f2559 (дата звернення: 01.02.2020).

5. Pilot judgments - European Court of Human Rights. URL: https://www.echr.coe.int/ Documents/FS_Pilot_judgments_ENG.pdf (дата звернення: 01.02.2020).

6. Burmych v. Ukraine two years later: What about restoral? URL: https://strasbourgobservers.com/ 2019/09/17/burmych-v-ukraine-two-years-later-what-about-restoral/ (дата звернення: 01.02.2020). 